\title{
PROJEKTNA METODA V IZOBRAŽEVANJU
}

Doc. dr. Nena

Mijoč

Filozofska

fakulteta

Univerze v

Ljubljani

\section{POVZETEK}

Projektna metoda $v$ izobraževanju odraslih in visokošolskem izobraževanju je dobra izbira zaradi naslednjih prednosti: poglablja uporabnost znanja, je naravna metoda učenja odraslih in povečuje notranjo motivacijo za samostojno izobraževanje. Odraslim omogoča neposreden prenos spoznanj v prakso, študentom pa daje potrebno samozavest in potrditev, da je znanje moč uporabiti v realnem življenju.

Teoretiki projektno metodo različno poimenujejo, in sicer projektno delo, projektno učenje, projektno učno delo ipd. Povezujejo jo z raziskovalnim pristopom, s študijo primera, problemskim poučevanjem, z učenjem ali poučevanjem s projekti, samostojnim učenjem, $z$ izkustvenim učenjem in še s čim. Nekateri govorijo o projektno zasnovanem učenju. Menimo, da je v izobraževanju odraslih pa tudi $v$ visokošolskem izobraževanju najenostavnejša in najsmotrnejša uporaba izraza "projektna metoda«. Za projektno metodo je ključnega pomena ciljna usmerjenost, samostojnost, odgovornost, dalj časa trajajoča zavzetost učečega in povezanost problema s prakso. Izraz je sicer star približno sto let, ko ga je prvič uporabil Kilpatrick za kmetijsko izobraževanje. So pa izobraževanje s projekti uporabljali že v šestnajstem stoletju $\checkmark$ Rimu in Parizu, v okviru študija arhitekture in tehnologije. Dandanes, ko je uporabnost znanj še kako aktualna, ko je samostojnost in odgovornost vseh, ki se izobražujejo, premalo poudarjena, je projektna metoda pogost odgovor na vprašanje, kako do kompetenc in ciljev, ki si jith zastavljamo v izobraževalnem procesu.

Aktualnost projektne metode v izobraževanju odraslih in visokošolskem izobraževanju je pogojena $\mathrm{z}$ več razlogi, na prvi pogled pa izstopata dva pragmatična razloga. Prvi je povezan s težnjo, da bi študenti pridobili kompetence, $\mathrm{ki}$ jih formalno šolanje in klasični akademski študij omogočata $v$ premajhni meri. Težimo torej $\mathrm{k}$ temu, da bi znali diplomanti naučeno znanje uporabljati $v$ praksi in ga preoblikovati $v$ dejanske spremembe v svojem okolju. Potrebe po uporabnosti in funkcionalnosti znanja ni potrebno posebej argumentirati, saj je to zelo pereč problem učinkovitosti celotnega šolstva $\mathrm{v}$ našem nacionalnem prostoru pa tudi v celotni Evropi. Drugi razlog za obravnavo pro- jektne metode je ta, da je projektna metoda zelo podobna naravnemu učenju pri delu in $\mathrm{v}$ življenju ljudi. Ko si zastavljamo zahtevne cilje, načrtujemo dejavnosti, ko izberemo strategije in vire in smo sredi procesa dela, naletimo na številne probleme in vprašanja, ki v nas izzovejo težnjo po spremembi. Spremenimo pogled na probleme, Projektna metoda je zelo podobna naravnemu se soočimo $z$ zastarelimi predsodki, izboljšsamo spretnosti, utrdimo ali spremenimo svoje vrednote. Vse to je učenje. Seveda pogosto tudi ugotovimo, da smo v svojih znanjih in spretnostih enostavno prešibki, da se bomo morali poglobiti, si za- 
staviti načrt in se do nekaterih novih znanj in spretnosti dokopati z odkrivanjem, s pomočjo drugih ljudi, z vajo, s preizkušanjem ... Postopno gradimo svoje lastne strategije, izberemo priljubljene, dostopne pa tudi nenavadne vire, učenje postane vsakdanja dejavnost, zavemo se, da sc naše zmožnosti dojemanja, opazovanja, analiziranja, kritičnega razmisleka, povzemanja in zastavljanja zahtevnejših načrtov izboljšujejo, da smo vse bolj učljivi in si znamo izbirati cilje in okolja, ki našo učljivost še pospešujejo.

Svoje učenje začenjamo načrtovati, priložnostno učenje se postopno spreminja $v$

\section{Projektna naloga} ima veliko motivacijsko moč. učenje s projekti, $v$ katere vstopamo samostojno ali v povezavi $z$ drugimi ljudmi. Kadar je cilj nenehnih načrtnih projektov predvsem pridobivanje novih znanj, spretnosti ali vrednot, bi lahko rekli, da se vseživljenjsko samovzgajamo, samoizobražujemo.

Ljudje si zastavljajo različne cilje. Mnogi se vsak dan soočajo $z$ vse večjimi in zahtevnejšimi nalogami pri svojem delu. Nekateri se želijo izpopolniti v uporabi nove tehnologije, drugi si želijo izboljšati spretnosti medsebojnega komuniciranja. Ljudje spremenijo svoje delo, se selijo ali preprosto morajo spremeniti slog svojega življenja. Mnogi si želijo izraziti svoje ideje in čustva v likovni, glasbeni ali kateri drugi umetnosti. Drugi se odločajo za samostojno gradnjo hiše ali za gradnjo male elektrarne. Mnogi radi potujejo, spoznavajo nove kraje in drugačne kulture, vzpostavljajo nove mostove in vezi med ljudmi. Vse to so projekti, s katerimi se učimo. Ko je A. Tough pred skoraj tridesetimi leti preučeval učenje odraslih, je ugotovil, da v povprečju vsak odrasel posameznik izpelje približno sedem učnih projektov $\mathrm{v}$ encm letu.

$S$ projektno metodo so se odrasli le redko srečali že v času začetnega šolanja. Metoda je izrinjena na rob in pomeni prej izjemo kot pa običajno obliko izobraževanja $v$ osnovni in srednji šoli. $V$ učinkovitostno naravnanem poučevanju, ki je pretirano tekmovalno usmerjeno in poudarja le doseganje učnih standardov in čim višjih številčnih ocen, je malo prostora za samostojne učne projekte, za razvijanje učenčevih intercsov in za spodbujanje radovednosti ter ustvarjalnosti posameznega učenca. A vendarle, učitelji, ki se zavedajo motivacijske moči samostojnih projektnih nalog, se tu in tam vendarle odločijo za projektno metodo.

\section{PROBLEM DEFINICIJE PROIEKTNE METODE}

»Projektna metoda obrne pravila poučevanja na glavo.r

Šolanje pa je pogosto drugačno. J. Dewey je prav tako že pred skoraj sto leti kritično pisal, da je učenje preveč oddaljeno od življenja, da se preveč ceni učenje na pamet in si skušajo učenci zagotoviti boljše rezultate s tem, ko

Načrtovani učni projekt je A. Tough opredelil kot zaporedje vsaj sedmih polurnih učnih epizod v daljšem časovnem obdobju (Tough, 1979). Učenje s projekti pa se ne pojavi nenadoma, z odraslostjo, razvija se postopno že od otroštva naprej in je pogostejše v najstniškem obdobju, ko se otroci zavedo, da niso več povsem odvisni od odraslih, da marsikaj zmorejo tudi sami. Takrat se širijo tudi njihovi interesi na najrazličnejša nova področja. Samostojno začnejo odkrivati svet okoli sebe, pojavljajo se zahtevna yprašanja, kako kaj deluje, in mnogi otroci se podajo v raziskovanje s pomočjo interneta, literature, pa tudi s samostojno dejavnostjo. Večkrat si poiščejo tudi neformalne mentorje. V šoli, ki teži k učinkovitemu prenosu čim večje količine predpisanih znanj, je za takšno odkrivanje pogosto premalo časa. 
Projektno metodo so poudarjali in opisovali že progresivni pedagogi, npr. Kilpatrick, pred skoraj sto leti (http://historymatters. gmu.edu/d/4954). Projekt je opredelil kot dejavnost, pri kateri sodeluje srce, s projektom resnično želimo doseči družbeno vreden cilj.

skušajo ugotoviti, kaj bi učitelji od njih radi slišali (Dewey, 1916; Kilpatrick, 1918). Vse to spodbuja besedno učenje, učenja, ki izvira iz življenjskih problemov in izzivov, pa se v šoli skoraj ne obravnava. Ali niso ta razmišljanja aktualna tudi danes?

V literaturi je v zadnjem času zaslediti tudi izraz »projektna pedagogika«, ki naj bi pomenil projektni pristop v načrtovanju kurikuluma. Projekt je poglobljen, dolgotrajen individualni ali skupinski proces, katerega rezultat je novo znanje ali nov izdelek. Sama beseda projekt (purjeter) pa izhaja iz francoščine in pomeni »vreči ven«, načrtovati. Pogosto uporabljajo projektni pristop kot metodo, s katero želijo študentom približati znanstveno raziskovalno delo in jih kot wzunanje sodelavce« uvesti $v$ raziskovalno in razvojno dejavnost. (http:// www.covis.northwestern.edu/geosciences/ philosophy/projects.html)

Č podrobneje pogledamo značilnosti projektne metode, hitro ugotovimo, da so pravila običajnega poučevanja obrnjena na glavo. Pri poučevanju učitelj izbere vsebine, zagotovi učne materiale in tudi oceni znanje učenca.
Pri projektni metodi pa je študent tisti, ki izbere vsebino projekta, se sam odloči, kje in katere vire bo uporabljal, analizira in povzame preučevane podatke, seveda potem izsledke tudi primerno predstavi. Projekt je proces, ki traja določen čas, pri tem pa učitelj namesto svoje učiteljske vloge zavzame vlogo svetovalca in mentorja.

\section{Je klasično učenje preveč oddaljeno od realnega življenja?}

jekt, skupina samostojno napiše tudi poročilo o projektu (Henry, 1994, str. 12, 13).

Navadno projekt obravnava določen problem, $z$ njim iščemo rešitev problema, pri tem pa interdisciplinarno povezujemo prej pridobljena znanja. Projekt praviloma pomeni načrtovanje, izdelovanje umetniške stvaritve, lahko pa tudi ciljno načrtovano učenje

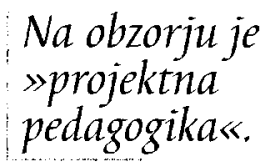
vnaprej določene spretnosti, osvojitev želenih vrednot, stališč ali zanimanj.

$S$ projektno metodo izobraževanja želimo predvsem izboljšati spretnosti samostojnega učenja, povečati motivacijo za učenje in izobraževanje, izboljšati zmožnosti integracije in uporabnosti znanj.

S projektno metodo, pri kateri so študenti bolj ali manj samostojni in je ucitelj le svetovalec, si študenti razvijajo pomembne sposobnosti, zmožnosti in kompetence samostojnega načrtovanja, odločanja, raziskovanja,

Projektna metoda v izobraževanju je skupen izraz za časovno daljše projekte, $s$ katerimi želimo doseči vnaprej načrtovane vzgojne in izobraževalne cilje. Pri tem je pomembna samostojnost, odgovornost in zavzetost učečih. Učitelj se dejansko spremeni v mentorja, svetovalca, učenje poteka $z$ odkrivanjem in konstruiranjem, $v$ središču je cilj projekta in oseba, ki se uči. Cilj projekta je lahko rešitev resničnega, perečega problema v nekem konkretnem okolju, ali pa iskanje odgovora na širši problem, ki ga je potrebno šele raziskati, proučiti. Prav zato je povezovanje projektne metode $\mathrm{z}$ drugimi izobraževalnimi metodami, kot je metoda primera ali problemsko zasnovano učenje, razumljivo in smiselno. Vendar gre v teh primerih pogosto za vnaprej precej natančno strukturirane dejavnosti, kjer je samostojnost udeležencev manjša kot pri projektni metodi, ki naj je ne bi preveč natančno načrtoval in strukturiral učitelj. 
reševanja problemov in vztrajanja pri doseganju ciljev.

Samostojnost, kot temeljna značilnost odraslega, prihaja vse bolj do izraza v izobraževanju z uveljavljanjem koncepta vseživljenjskosti učenja. Za doseganje novih in zahtevnejših ciljev se ne moremo pripraviti vselej z izobraževanjem; s tečaji in seminarji, bodisi zato, ker nimamo dovolj sredstev, da bi odpotovali tja, kjer izobraževanje ponujajo, bodisi zato, ker zaradi dela ali družine ne moremo odpotovati takrat, ko so tečaji na voljo. Tudi izobraževanje na daljavo še ni dostopno za najrazličnejša specifična znanja. $\mathrm{Na}$ probleme, ki izvirajo iz nepredvidenih zapletov pri delu ali $\mathrm{v}$ življenju, se ne moremo vselej vnaprej pripraviti. V skupinskem izobraževanju pogosto iščemo odgovore samostojno, s pogovori z ljudmi, ki so imeli podobne probleme, brskamo po internetu, beremo strokovno literaturo in, če so problemi res zapleteni, začnemo kovati strategijo učenja, da bi jih zmogli reševati. Samostojnost, ne le $\mathrm{v}$ priložnostnem in izkustvenem učenju, temveč tudi $v$ formalnem in neformalnem izobraževanju, je vse odločilnejša za doseganje ciljev.

Če bi bili dosledni, bi projektno metodo imenovali samo tisto izobraževalno metodo, kjer študenti v celoti raziščejo problem, ki si ga sami zastavijo, sami poiščejo vire in temeljna vprašanja, na katere tudi sami odgovorijo,

V praksi se je vzpostavilo vě́ različic projektne metode. pripravijo o tem poročilo in ga predstavijo. Vendar je $\mathrm{v}$ praksi več variant projektne metode, kjer predavatelj oz. mentor vnaprej pripravi naslove vsebin, primerne za projektno metodo, udeleženci izobraževanja pa si potem izberejo enega izmed naslovov. Pogosto predavatelj tudi svetuje način dela in vire ter morda pomaga $z$ vnaprej pripravljenim vprašalnikom, $s$ testom ali z lestvico stališč. To so že bolj strukturirani projekti in pomagajo študentom posebej

takrat, ko se bodisi prvič soočajo s projektno metodo oziroma takrat, ko podobne teme doslej še niso obravnavali. Neredko pa profesorji predlagajo študentom reševanje resničnih problemov. Kljub bojazni, da študenti še niso usposobljeni za reševanje resničnih problemov v praksi, se je izkazalo, da so mnoge rešitve $v$ podjetjih tudi s pridom uporabili. Zgodi se, da imajo študenti glede problema premalo izkušenj, a so podjetja, ki »posodijo« probleme, do študentov in njihovih izsledkov zelo prizanesljiva (Schuldt, 1991; Usher idr., 1991; povzeto po Henry, 1994).

Med projektno metodo lahko pogojno štejemo tudi kratke, zelo strukturirane projekte, ki jih imenujemo projektne naloge. Na primer, udeležencem predlagamo, da preberejo izsledke raziskave o učenju zunaj šole in nato $v$ roku enega tedna vsak vpraša tri osebe, česa novega so se naučili $v$ preteklih šestih mesecih zunaj šole.

Če zelo razširimo pojem projektne metode, bi lahko k njim prišteli tudi razširjene referate, študije primerov ali simulacije. $\mathrm{V}$ obsežni študiji je bilo ugotovljeno, da ni posebnih ovir in lahko projektno metodo uporabljamo pri vseh predmetih na visokošolski ravni, a je bila doslej največkrat uporabljena pri uporabnih znanostih, kot so arhitektura, oblikovanje, tehnične vede, kmetijske vede (Henry, 1994), pa tudi v izobraževalnih vedah in pri socialnem delu.

Projektna metoda je torej izobraževalna metoda, kjer v daljšem časovnem obdobju posameznik ali skupina izbere zanjo nov problem in vire, preučuje, analizira in interprctira problem s ciljem, da bi dosegla zastavljeni cilj. Svoje dosežke praviloma predstavi pisno in ustno pred skupino. Pri tem so posamezniki običajno zavzeti, samostojni in odgovorni, znajo pa tudi poiskati pomoč in svetovanje mentorjev in strokovnjakov. 


\section{DELEŽ PROJEKTOV V}

IZOBRAŽEVALNEM PROGRAMU IN STOPNJA STRUKTURIRANOSTI PROJEKTNE METODE

Temeljno vprašanje pri vključevanju projektne metode v izobraževalni program je, ali bo projektna metoda vodilna metoda nekega modula ali le ena izmed metod, navadno kombinirana s predavanji, seminarji in vajami. Obe možnosti sta sprejemljivi, vendar moramo težo projektne metode $\mathrm{v}$ programu vnaprej predvideti. $V$ programih, kjer celotni modul sloni na enem ali na več projektih, se učitelj $o z$, predavatelj dejansko spremeni $\mathrm{v}$ mentorja in svetovalca študentom. To je zelo zahtevna naloga, na katero niso pripravljeni vsi učitclji. Zato obstaja velika nevarnost, da bodo učitelji delo študentov $\mathrm{v}$ strahu pred premajhno strukturiranostjo študentovega učenja poskušali čim bolj strukturirati. Tako se lahko zgodi, da se projektno delo spremeni v laboratorijsko delo po natančnem receptu. Druga skrajnost pa lahko pomeni popolno prepuščenost študenta pri projektnem delu, posebej, če učiteljeva dostopnost ni zagotovljena ali je ta celo dalj časa odsoten. Večinoma je praksa nekje vmes. Glede strukturiranosti projektne metode upoštevamo več med seboj prepletenih dejavnikov: vzgojno-izobraževalne cilje projektne metode, seznanjenost študentov in njihovo izurjenost pri projektni metodi, učiteljeve izkušnje $s$ projektno metodo, vsebinsko področje in dostopnost virov znanja in možnosti preučevanja prakse. $\mathrm{Z}$ vidika razvijanja samostojnosti študentov pri učenju bi bilo učenje s projekti priporočljivo čim manj strukturirati. Vendar izkušen mentor kmalu ugotovi, da nekateri študenti, ki še niso vešči načrtovanja svojega časa, usklajevanja dela in samostojnega odkrivanja novih virov, potrebujejo svetovanje.
Projektna

metoda mora biti strukturirana.
Pogosto jim lahko pri organizaciji in vodenju dokumentacije o projektu in pri načrtovanju dela pomaga tudi strokovna literatura, $\mathrm{ki}$ obravnava skupinsko študijsko delo (Mijoč, Krajnc in Findeisen, 1993), pa tudi gradiva, ki pomagajo načrtovati delovni ali izobraževalni proces (Knowles, 1970, str. 259-264).
Študenti zelo cenijo projektno metodo pri svojem študiju.
Strukturiranost projektne

metode je $\mathrm{v}$ osnovi vendarle nujno potrebna.

$\mathrm{V}$ ta namen mentor jasno opredeli, kakšni so pričakovani rezultati projekta, npr. pisno poročiloo projektu, struktura pisnega poročila ter način predstavitve izsledkov ciljni skupini (neposredno ali preko medijev).

$\mathrm{Na}$ začetku projekta mentor predstavi osnovne faze projekta, in sicer:

- odločanje o temi

- zastavljanje ciljev

- načrtovanje dela

- izbiro virov

- analizo in interpretacijo zbranih podatkov

- pisanje poročila.

Faze se med seboj prepletajo in niso nujno linearne. Vire pravzaprav zbiramo ves čas, od začetka projekta pa do zaključne faze.

Glede na definicijo, da so pravi projekti predvsem tisti, pri katerih študenti večino izobraževalnega procesa izpeljejo sami, se bomo zavzemali za čim manjšo strukturiranost projektne metode in raje spodbujali študente, da sami oblikujejo vprašanja in poiščejo pomoč profesorja, kadar problema ne morejo rešiti. Spomnimo se, da večja samostojnost pri projektni metodi pomeni tudi večjo samostojnost pri kasnejšem strokovnem in raziskovalnem delu, pa tudi pri samoizobraževanju in strokovnem izpopolnjevanju. Posledično pa pomeni tudi večjo samozavest pri prvih samostojnih korakih v stroki. 


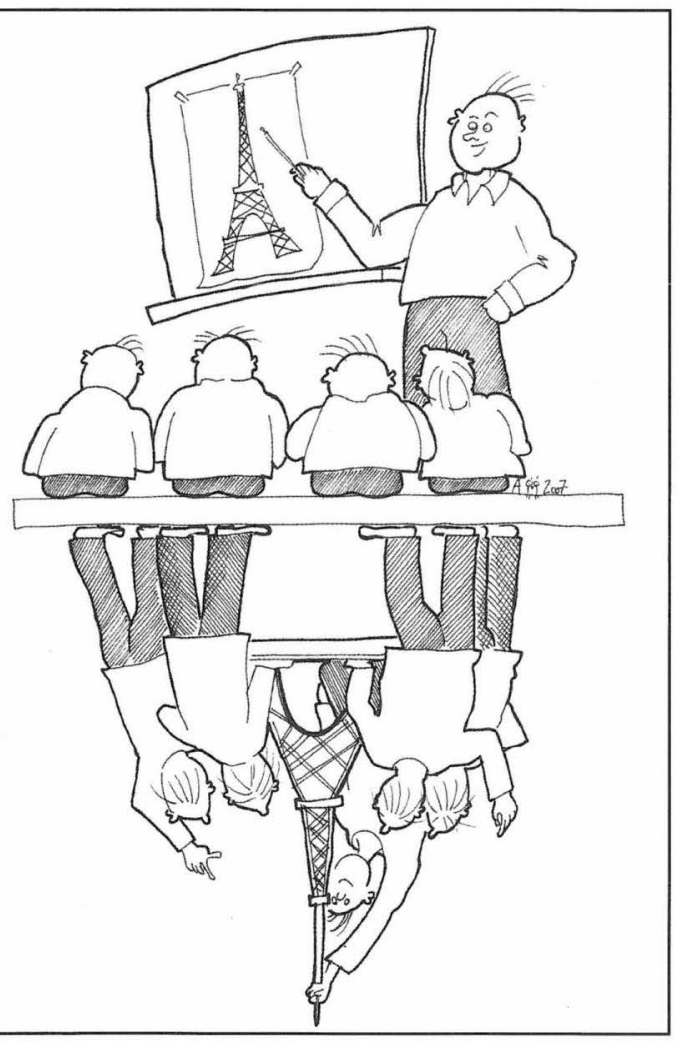

Prav tako je dobro opozoriti tiste, ki se prvič srečujejo s projektno metodo, da mora biti načrtovanje dela prožno in prilagodljivo.

\section{Projektna metoda} poudarja izkustveno ucenje.
Pri skupinskem projektu je dobro upoštevati tudi dodaten potreben čas za usklajevanje in reševanje komunikacijskih ovir. Kadar smo pri predstavitvi projektnih rezultatov zahtevnejši in pričakujemo prilagoditev predstavitve ciljni publiki, je lahko ta del celo samostojen podprojekt.

Študenti se na začetku lahko zelo prestrašijo svoje nove vloge $\mathrm{v}$ študijskem procesu. Kar naenkrat se morajo iz pasivne vloge slušateljev predavanj preleviti $\mathrm{v}$ aktivne iskalce zapletenih vprašanj in odgovorov. Hkrati se, če je projekt skupinski, učijo tudi mnogih socialnih kompetenc. Kdo naj bo vodja skupine, kako naj poteka načrtovanje projektnega dela, kaj storiti, če se posamezni člani ne odzivajo in ne izpolnjujejo dogovorjenih obveznosti? Kakšna so pričakovanja glede kakovosti in obsežnosti končnega izdelka? Ali bodo projekti ocenjeni, kdo jih bo ocenjeval, kakšna bo teža te ocene $v$ primerjavi $z$ drugimi ocenami pri predmetu. Na takšna in podobna vprašanja se mentor vnaprej pripravi.

Po večletni uporabi projektne metode pri študiju andragogike na Filozofski fakulteti in analizi pisnih razmišljanj študentov o projektni metodi ugotavljamo, da so študenti praviloma zelo zavzeti pri pripravi prvih skupinskih projektov. Pri tem seveda na začetku ne manjka strahu pred neuspehom in po prvem navdušenju tudi pogostih spraševanj, čemu nov pristop $\mathrm{k}$ študiju. Ko se prvič srečajo s skupinsko projektno metodo, so študenti bolj osredotočeni na proces medsebojnega načrtovanja, usklajevanja in komuniciranja. Kasneje, ko projektno metodo že bolje poznajo in osvojijo, pa se močneje poglobijo $\mathrm{v}$ vsebino in zavzeto zasledujejo cilj, ki si ga zastavijo.

Ena izmed študentk takole opisuje svoje izkušnje in spoznanja: "Bile smo dokaj organizirane, nekaj težav smo imele s kolegico, ki ni reševala svojih nalog. Vendar smo s pogovorom tudi to uredile ... tako je šlo $v$ bistvu $v$ okviru projekta pri meni tudi za samoizobraževanje (ki ga sicer ni nihče nadziral), kjer sem se tudi sama veliko naučila in uporabila nekatere nove metode in tehnike tudi zase ... Moje najpomembnejše spoznanje je, da smo za svojo samopodobo odgovorni sami in smo mi tisti, ki se moramo truditi za to, da se bomo dobro počutili v svoji koži.« Ugotavljamo tudi, da so mnogi izredni študenti z večletnimi delovnimi izkušnjami zelo 
vešči in samozavestni pri izdelavi skupinskih projektov. Novo zanje pa je, da se zavejo, da se lahko skupaj lotevajo tudi novih raziskovalnih in izobraževalnih projektov in ozavestijo povezanost učenja v učilnici, v življenju in pri delu. Tako se začenjajo zavedati, da resnični projekt $\mathrm{i}$ in projektna metoda $v$ izobraževanju lahko $v$ veliki meri pospešijo njihovo usposobljenost in izobraženost. To je v nasprotju s prevladujočim mnenjem nekaterih učiteljev in izobraževalcev, $\mathrm{ki}$ še vedno prisegajo le na tradjcionalne oblike izobraževanja, kot so tečaji, seminarji, delavnice, predavanja, inštrukcije in demonstracije.

Projektna metoda izobraževanja lahko obravnava študijska vprašanja in probleme (kot probleme raziskovanja ali samostojnega odkrivanja študija) ali pa se osredotoči na resnične probleme v okolju zunaj izobraževalne institucije, v kateri poteka študij. Slednji problemi so navadno bolj avtentični in še močneje motivirajo učeče. $V$ teh primerih imajo študenti dva mentorja, enega v okviru študijskega procesa in drugega $v$ delovnem okolju, na uspeh projektnega dela pa neredko vpliva raven komunikacije med obema, dobro načrtovanje in resnična zavzetost vseh vpletenih za doseganje vzgojnih, izobraževalnih ter projektnih namenov in ciljev.

Projektna metoda je po temeljnih značilnostih metoda izkustvenega izobraževanja, saj že v osnovi zajema vse tri temeljne kriterije, kot so visoka zavzetost, lastna kontrola ter povezanost $\mathrm{z}$ resničnim življenjem in delom.

Vse bolj se uveljavlja tudi pri izobraževanju na daljavo, še posebej pri e-izobraževanju, kjer nudi številne možnosti individualizacije pa tudi povezovanja udeležencev izobraževanja, ki delajo v skupinskih projektih.

\section{LITERATURA}

Boud, D., Cohen, R., Sampson, J. (2001). Peer Learning in Higher Education. London, New York: Kogan Page. Boud, D., Solomon, N. (2001). Work-based Learning, A
New Higher Education? Open University Piess.

Henry, J. (1994). Teaching Through Projects. London: Kogan Page.

Howell, R. T. (2003). The Importance of the Project Methods in Technology Education. Journal of Industrial Teacher Education, 3, str. 79-84, http://scholar.lib. vt.edu/ejournals/JITE/v40n3/howell.htm]\#howell2003 Illeris, K. (ur.) (2004). Learning in Working Life. Roskilde University Press.

Kilpatrick, T. H. (1918). The Project Method. Teachers College Record, 19, str. 319-334 (http://historymatters. gmu.edu/d/4954; 3. 11. 2007).

Knoll, M. (1997). The Project Method: Its Vocational Education Origin and International Development. Journal of Industrial Teacher Education, 3, str. 59-80 (http:/scholar.lib.vt.edu/ejournals/JITE/v34n3/Knoll. html; 3. 11. 2007).

Knowles, M. (1970). The modern practice of adult education. Association Press.

Krajnc, A. (1979). Metode izobraževanja odraslih. Ljubljana: Delavska enotnost.

Mijoč, N., Krajnc, A., Findeisen, D. (1993). Študijski krožki. Ljubljana: ACS.

Novak, H. (1990). Projektno uěno delo: drugačna pot do znanja. Ljubljana: DZS

Rudestam, K. E., Schoenholtz-Read, J. (2002). Handbook of Online Learning, Innovations in Higher Education and Corporate Training. Sage Publications.

Schultz, A. E. (2003). What We Teach and Why we Teach it. Journal of Industrial Teacher Education, 1, sir. 83-87, http://scholar.lib.vt.edu/ejournals/JITE/v37n] $/$ schultz.htm]

Tough, A. (1973). The Adult's Learning Projects. Toronto: OISE.

http://www covis nort hwestern edu/geosciences/philosophy/projects.html

Walter, G., Marks, S. (1981). Experiential Learning and Change. ZDA and Kanada: John Willey \& Sons.

Warner Weil, S., McGill, I. (1989). Making Sense of Experiential Learning, diversity in theory and practice. Open University Press. 